\title{
KAJIAN HUKUM ISLAM TERHADAP HAK MEREK SEBAGAI OBYEK DALAM PERJANJIAN RAHN
}

\author{
Khoirul Hidayah \\ Fakultas Syariah UIN Maulana Maliki Malang \\ khoirul.hidayah@yahoo.co.id
}

\begin{abstract}
Abstrak
Trademark right is industry property right that can to be company reputation and can protect the consumen from infringement. Trademark has economic value more than the other company assets.The fenomena about syariah economic in Islamic finance in Indonesia had to be interesting topic to study about trademark right as the object in rahn contract. The private law of Indonesia had explain that trademark right is the immovable intangible object. Trademark right can move to the other people. It can be sold and be inherited, hibah, and contract. In Islamic law studies, Ulama Hanafiah explain that the trademark as marhun, because it fulfill the requirement of rahn contract. MUI explain too about trademark in fatwa MUI in 2005. It explain that the trademark is huquq maliyah (property right)and it protect by the law.
\end{abstract}

Hak merek merupakan hak kekayaan industri yang dapat melindungi reputasi perusahaan dan konsumen. Hak merek dianggap mempunyai nilai ekonomis yang tinggi dibandingkan asset perusahaan yang lain. Fenomena semakin banyaknya minat para pelaku usaha yang tertarik terhadap pembiayaan yang berbasis syariah telah menjadi latar belakang yang menarik untuk mengkaji tentang hak merek sebagai obyek dalam perjanjian rahn. Hukum positif yang berlaku di Indonesia telah mengakui bahwa hak merek merupakan benda yang bergerak dan tidak berwujud. Hal ini berdasarkan pada hak merek yang dapat dijadikan sebagai benda yang dapat dimiliki, dialihkan dan bernilai ekonomis. Pada kajian hukum Islam yaitu menurut ulama Hanafiah, hak merek dapat dijadikan sebagai marhûn, karena telah memenuhi rukun dan syarat sebagai marhûn dalam perjanjian rahn. MUI juga menjelaskan melalui fatwanya yaitu tahun 2005 yang menjelaskan bahwa hak merek merupakan huqûq mâliyah (hak kekayaan) yang mendapat perlindungan hukum seperti mâll harta.

Kata Kunci : Merek, Harta kekayaan, Rahn.

Praktek perdagangan pada era globalisasi telah menuntut perkembangan hukum bisnis yang mampu menjawab permasalahan-permasalahan yang dihadapi oleh para pelaku usaha. Penambahan modal usaha melalui pembiayaan maupun kredit yang berasal dari lembaga pembiayaan baik dari lembaga perbankan atau non bank telah menjadi pilihan yang mampu membantu perkembangan usaha. Pembiayaan usaha dalam bentuk penambahan modal melalui pembiayaan syariah telah menjadi alternative bentuk pembiayaan yang mampu membantu dalam permasalahan permodalan. Salah satu dasar perjanjian adalah dengan menggunakan akad rahn.

Rahn menurut Imam Taqiyyudin abu Bakar Al Husaini dalam kitabnya Kifâyatul Ahyâr fii Halli Ghâyati al Ikhtisâr berpendapat bahwa rahn adalah perjanjian utang piutang dengan menjadikan harta sebagai kepercayaan atau penguat hutang dan yang memberi pinjaman berhak menjual barang yang digadaikan itu pada saat ia menuntut hak-nya. Dalam praktek perdagangan, perjanjian rahn lebih banyak menggunakan obyek benda emas, surat berharga dan barang-barang elektronik. Merek adalah salah satu bentuk dari reputasi 
perusahaan. Para pelaku usaha mempunyai banyak kepentingan dalam melindungi merek ketika bersaing di pasar global. Persaingan usaha semakin kompetitif seiring dengan munculnya arus globalisasi. Para pelaku usaha wajib melindungi mereknya melalui pendaftaran merek, sehingga mereknya mempunyai perlindungan hukum terhadap pelanggaran merek yang dapat merugikan pelaku usaha. Sebagaimana kita ketahui bahwa Hak atas Kekayaan Intelektual (HKI) atau Intellectual Property Rights (IPRs) merupakan hak ekonomis yang diberikan oleh hukum kepada seorang pencipta atau penemu maupun suatu hasil karya dari kemampuan intelektual manusia. Seiring dengan perkembangan dalam perdagangan, fenomena munculnya perlindungan hukum atas Hak Kekayaan Intelektual (HKI) sebagai hak yang dapat dialihkan kepada pihak lain telah menarik perhatian penulis untuk mengkaji apakah hak merek sebagai bagian dari HKI dapat dijadikan sebagai obyek di dalam perjanjian rahn.

Kajian hak merek sebagai objek dalam perjanjian rahn diharapkan mampu menjadi alternatif solusi dalam praktek pembiayaan dengan system syariah. Artikel ini akan membahas hak merek sebagai obyek dalam perjanjian rahn lebih mendalam melalui perpektif hukum Islam dan juga menurut perspektif hukum positif. Kajian perpektif hukum positif dilakukan adalah dikarenakan karena penyelesaian sengketa dalam lembaga pembiayaan syariah masih merujuk pada hukum positif.

\section{Hak Merek}

Hak merek merupakan hak kekayaan industri yang dilindungi oleh sistem HKI. Merek adalah tanda yang berupa gambar, nama, kata, huruf-huruf, angka-angka, susunan warna, atau kombinasi dari unsur-unsur tersebut yang memiliki daya pembeda dan digunakan dalam kegiatan perdagangan barang atau jasa (UUM). Pengaturan merek di Indonesia pertama kali diatur melalui UndangUndang Nomor 19 Tahun 1992 dan telah diubah dengan Undang-Undang Nomor 14 Tahun 1997 tentang Perubahan atas UndangUndang Nomor 19 Tahun 1992 tentang
Merek.Setelah ratifikasi keanggotaan WTO pada tahun 1994, selanjutnya pengaturan merek dilakukan penyesuaian dengan TRIPs melalui Undang-Undang Nomor 15 Tahun 2001 tentang Merek.

Hak atas merek menurut UndangUndang Merek (UUM) adalah hak eksklusif yang diberikan oleh negara kepada pemilik merek yang terdaftar dalam daftar umum merek untuk jangka waktu tertentu dengan menggunakan sendiri merek tersebut atau memberikan izin kepada pihak lain untuk menggunakannya (Pasal 3 UUM). Menurut Pasal 28 UUM, merek terdaftar mendapat perlindungan hukum untuk jangka waktu 10 (sepuluh) tahun sejak tanggal penerimaan dan jangka waktu perlindungan itu dapat diperpanjang.

Perlindungan merek sangat penting sekali, merek selain sebagai harta kekayaan yang dapat menghasilkan keuntungan bagi pengusaha (pemilik merek), juga sebagai alat untuk melindungi masyarakat selaku konsumen dari terjadinya penipuan kwalitas barang tertentu. Konsumen akan merasa dirugikan jika merek yang mereka anggap berkwalitas, ternyata diproduksi oleh pihak lain dengan kwalitas rendah. Hal ini juga bisa berakibat menurunkan reputasi perusahaan.

Pembagian merek menurut UUM ada 2 yaitu: (1) Merek dagang adalah merek yang digunakan pada barang yang diperdagangkan oleh seseorang atau beberapa orang secara bersama-sama atau badan hukum untuk membedakan dengan barang-barang sejenis lainnya. Contoh: KFC, Yamaha, Tupperware, dan lain-lain; (2) Merek jasa adalah merek yang digunakan pada jasa yang diperdagangkan oleh seseorang atau beberapa orang secara bersama-sama atau badan hukum untuk membedakan dengan jasa-jasa sejenis lainnya. Contoh: BRI, TUV Rheinland (jasa sertifikasi), AKAS (jasa transportasi), dan lain-lain; (3) Merek kolektif adalah merek yang digunakan pada barang dan/atau jasa dengan karakteristik yang sama yang diperdagangkan oleh beberapa orang atau badan hukum secara bersama-sama untuk membedakan dengan barang dan/atau jasa sejenis lainnya. Contoh: Melinda Collective Marks, merek ini digunakan oleh 
5200 anggota dari 16 koperasi yang beroperasi di Valle di Non dan Valle di Sole, Italia. ${ }^{1}$

\section{Perjanjian Rahn}

Perjanjian rahn adalah perjanjian yang berawal dari perjanjian hutang piutang. Rahn dalam istilah Islam sering disebut sebagai jaminan. Rahn secara etimologi memiliki arti al tsubut (tetap) yang mempunyai beberapa pengertian. Rahn juga memiliki arti lain yaitu tertahan, seperti terdapat dalam al-Quran surat Muddatstsir ayat 38 yang berbunyi:

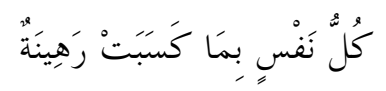

Artinya: "Tiap-tiap diri bertanggung jawab (tertahan) atas apa yang telah diperbuatnya." (QS.Al-Muddatstsir: 38)

Kata rahinah dalam hal ini diartikan tertahan, sebagaimana kita ketahui barang jaminan gadai biasanya dikuasai oleh debitur. ${ }^{2}$ Rahn dalam kamus istilah keuangan dan perbankan syariah Bank Indonesia Direktorat Perbankan Syariah mengartikan bahwa rahn adalah penyerahan barang sebagai jaminan untuk mendapatkan hutang. Rahn memiliki definisi dalam terminologi figh secara umum yaitu menahan suatu barang dengan suatu hak yang memungkinkan dapat dipenuhi dari barang tersebut, artinya barang tersebut dijadikan penguat atau jaminan terpenuhinya hak. ${ }^{3}$

Ada beberapa definisi yang dikemukakan oleh ulama fiqh. Ulama Mazhab Maliki mendefinisikan rahn sebagai harta yang bersifat mengikat. Ulama Mazhab Hanafi mendefinisikan rahn dengan, "menjadikan sesuatu (barang) sebagai jaminan terhadap hak (piutang) yang mungkin dijadikan sebagai pembayar hak (piutang) tersebut, baik seluruhnya maupun sebagiannya". Ulama Mazhab Syafi'i dan Mazhab Hanbali

\footnotetext{
${ }^{1}$ Tomi Suryo Utomo, Hak Kekayaan Intelektual di Era Globalisasi, (Yogyakarta: Graha Ilmu, 2010), h. 211

${ }^{2}$ Abdullah bin Muhammad ath-Thayar, Abdullah bin Muhammad al-Muthliq, dan Muhammad bin Ibrahim Alu Musa, Al-Fiqh Al-Muyassarah: Qismul Mu'amalah (Riyadh: Madar al-Wathani lin Nasyr, 1425 H), h. 115.

${ }^{3}$ Wahbah Al-Zuhaili, Al-Mu'amalat Al-Maliyyah AlMu'ashirah Buhuts Wa Fatawa Wa Hulul (Beirut : Dar Al-Mu'ashirah, 2002), h. 82.
}

mendefinisikan rahn dalam arti akad, yaitu "menjadikan materi (barang) sebagai jaminan utang yang dapat dijadikan pembayar utang apabila orang yang berutang tidak bisa membayar utangnya itu".

Pelaksanaan rahn dalam Islam memiliki ketentuan tersendiri diantaranya adalah akad yang digunakan terkait penyerahan suatu barang oleh rahîn kepada murtahin sebagai jaminan untuk mendapatkan hutang. ${ }^{4}$ Kemudian syarat dan rukun rahn juga harus terpenuhi seperti yang dijelaskan dalam kompilasi hukum ekonomi Islam diantaranya adalah para pihak yang melakukan akad gadai harus memiliki kecakapan hukum, harta gadai harus bernilai dan dapat diserah terimakan, harta gadai harus ada ketika akad dibuat, perjanjian rahn dapat dilaksanakan dengan memenuhi ketentuan rukun sebagai berikut: (1) Penerima rahn (rahin); (2) Pemberi rahn (murtahin); (3) Harta rahn (marhun); (4) Hutang (marhun bih); dan (4) Ijab qabul. ${ }^{5}$

Akad yang dimaksud di atas adalah harus dinyatakan oleh para pihak dengan cara lisan, tulisan, ataupun dengan isyarat. Sedangkan syarat-syarat rahn para ulama fiqh menyusunnya sesuai dengan rukun rahn itu sendiri. Dengan demikian syarat-syarat rahn adalah: ${ }^{6}$ (1) Syarat yang terkait dengan orang berakad (rahin dan murtahin) adalah cakap bertindak hukum. Kecakapan bertindak hukum, menurut jumhur ulama adalah orang yang telah baligh dan berakal. Sedangkan menurut ulama Hanafiyah kedua belah pihak yang berakad tidak disyaratkan baligh, tetapi cukup berakal saja. Oleh sebab itu, menurut mereka anak kecil yang mumayyiz boleh melakukan akad rahn asal mendapat persetujuan dari walinya; (2) Syarat yang terkait dengan shighat, ulama Hanafiyah berpendapat bahwa dalam akad rahn tidak boleh dikaitkan oleh syarat tertentu. Dikatakan demikian, karena akad rahn sama dengan akad jual beli. Apabila akad rahn dibarengi dengan syarat tertentu maka syaratnya batal meskipun akadnya sah. Misalnya, orang berutang mensyaratkan

\footnotetext{
${ }^{4}$ Kodifikasi produk perbankan syariah, h. 85

${ }^{5}$ Peraturan Mahkamah Agung Nomor 2 Tahun 2008 tentang Kompilasi hukum ekonomi Islam

${ }^{6}$ Abdul Rahman Ghazaly, Ghufron Ihsan, Sapiudin Shidiq, Fiqh Muamalah (Jakarta: Kencana Prenada, 2010), h . 267-268
} 
apabila tenggang waktu utang telah habis dan hutang belum dibayar, maka jaminan atau rahn itu diperpanjang satu bulan. Sementara, jumhur ulama mengatakan bahwa apabila syarat tersebut ialah syarat yang mendukung kelancaran akad, maka syarat itu dibolehkan. Namun apabila syarat itu bertentangan dengan sifat dari akad rahn, maka syaratnya batal. Perpanjangan rahn selama satu bulan sebagaimana disebutkan pada contoh merupakan syarat yang tidak sesuai dengan sifat rahn, sehingga dinyatakan batal. Syarat yang dibolehkan itu misalnya, untuk sahnya rahn, pihak pemberi hutang minta agar akad itu disaksikan oleh dua orang saksi; (3) Syarat yang terkait dengan hutang (marhun bih): (a) Merupakan hak yang wajib dikembalikan kepada yang memberi hutang; (b) Hutang itu boleh dilunasi dengan jaminan; dan (c) Hutang tersebut jelas dan tertentu; (4) Syarat yang terkait dengan barang yang dijadikan jaminan (marhun), menurut ulama fiqh syarat-syaratnya adalah sebagai berikut: (a) Barang jaminan itu boleh dijual dengan nilainya seimbang dengan hutang; (b) Berharga dan boleh dimanfaatkan; (c) Jelas dan tertentu; (d) Milik sah orang yang berhutang; (e) Tidak terkait dengan hak orang lain; (f) Merupakan harta utuh; dan (g) Boleh diserahkan materinya maupun manfaatnya.

Disamping syarat-syarat di atas, para ulama fiqh sepakat menyatakan bahwa ar-rahn itu baru dianggap sempurna apabila barang yang dirahn-kan secara hukum sudah berada di tangan pemberi utang, dan uang yang dibutuhkan telah diterima peminjam uang. Syarat yang terakhir (kesempurnaan ar-rahn) oleh para ulama disebut sebagai qabdh almarhûn (barang jaminan dikuasai secara hukum). Syarat ini menjadi penting karena Allah dalam surat al-Baqarah ayat 283 menyatakan "fa rîhânun magbûdhah" yang memiliki makna barang jaminan itu dikuasai secara hukum.

Kemudian apabila barang jaminan itu telah dikuasai oleh pemberi utang, maka akad ar-rahn bersifat mengikat bagi kedua belah pihak. Oleh sebab itu, utang selalu terkait dengan barang jaminan, sehingga apabila utang tidak dapat dilunasi, barang jaminan dapat dijual. Namun ketika dalam penjualan barang jaminan itu ada kelebihan, maka wajib dikembalikan kepada pemiliknya. ${ }^{7}$ Berikut ini adalah perbedaan rahn dan gadai: (a) Rahn dalam hukum Islam dilakukan secara sukarela atas dasar tabarru', sedangkan gadai dalam hukum perdata disamping tolong-menolong juga terdapat tujuan profît yaitu dengan cara mengambil bunga yang sudah ditentukan. (b) Hak gadai dalam hukum perdata berlaku pada benda yang bergerak, sedangkan dalam hukum Islam, rahn berlaku pada seluruh harta, baik harta yang bergerak maupun yang tidak bergerak. (c) Rahn, menurut hukum Islam tidak ada istilah bunga utang, yang ada hanyalah sewa tempat.

Landasan hukum perjanjian rahn adalah merujuk pada hukum Islam yang bersumber dari Al-Qu'ran dan Hadist Nabi SAW. Berikut ini adalah yang menjadi dasar hukum perjanjian rahn: (1) Al Qur'an surat al Baqarah ayat 283 yang artinya: "Jîka kamu dalam perjalanan (dan bermu'amalah tîdak secara tunâ̂) sedang kamu tîdak memperoleh seorang penulîs, maka hendaklah ada barang tanggungan yang dîpegang (oleh yang berpîutang). Akan tetapî jîka sebagîan kamu mempercayầ sebagîan yang laîn, maka hendaklah yang dîpercayầ îtu menunaîkan amanatnya (hutangnya) dan hendaklah $\hat{\imath} a$ bertakwa kepada Allah Tuhannya; dan janganlah kamu (para saksî) menyembunyîkan persaksîan dan barang sîapa yang menyembunyîkannya, maka sesungguhnya îa adalah orang yang berdosa hatînya; dan Allah Maha Mengetahuî apa yang kamu kerjakan." (2) Hadits Nabi yang diriwayatkan oleh Muslim dari Aisyah: "Darî Aîsyah berkata: Rasulullah Saw membelî makanan darî seorang Yahudî dan menggadaîkannya dengan besî̀"(HR. Muslim dan Aisyah). "Darî Anas r.a bahwasanya $\hat{\imath} a$ berjalan menuju Nabî SAW dengan rotî darî gandum dan sungguh Rasulullah SAW telah menaguhkan baju besî kepada seorang Yahudî dî Madînah ketîka belîau mengutangkan gandum darî seorang Yahudî'(HR. Anas); (3) Ijma' ulama atas hukum mubah (boleh) pada perjanjian rahn. Adapun mengenai Prinsip rahn telah memiliki fatwa dari Dewan Syari ah Nasional Majelis Ulama Indonesia (DSN-MUI) yaitu fatwa

\footnotetext{
${ }^{7}$ Ibn Rusyd, Bidayatul Mujtahid Wa Nihayatul Muqtashid, II, h. 268
} 
Khoirul Hidayah, Kajian Hukum Islam Terhadap Hak Merek...| 5

Nomor 25/DSN-MUI/III/2002 tentang Rahn dan fatwa Nomor 26/DSN-MUI/III/2002 tentang Rahn Emas.

\section{Hak Merek Sebagai Benda}

Hak merek merupakan hak khusus yang diberikan oleh pemerintah kepada pemilik merek untuk menggunakan dan atau mengijinkan untuk menggunakannya kepada orang lain (Pasal 3 UU merek). Sebuah merek dapat menjadi sebuah kekayaan yang amat berharga secara komersial. Merek perusahaan dapat menjadi lebih bernilai dibandingkan dengan asset riil perusahaan tersebut. ${ }^{8}$ Hak merek bisa dikatakan sebagai benda (zaak dalam Belanda) sebagaimana dikenal dalam hukum perdata. Menurut L.J Van Apeldorn benda dalam arti yuridis merupakan obyek hukum. ${ }^{9}$ Obyek hukum adalah segala sesuatu yang dapat digunakan subyek hukum (orang atau badan hukum) dan dapat menjadi obyek dalam hubungan hukum, karena sesuatu itu (obyek) dapat dikuasai oleh subyek hukum. ${ }^{10}$ Pada pengertian tersebut, benda diartikan sebagai segala sesuatu yang dapat menjadi obyek hukum atau dapat 'dihaki' oleh orang menurut hukum dan mempunyai nilai ekonomi, sehingga hak merek sebagai benda merupakan harta kekayaan yang dapat dialihkan kepada pihak lain, baik dalam bentuk jual beli, pewarisan, hibah atau perjanjian khusus seperti lisensi. Hak merek merupakan jenis benda bergerak tidak berwujud (intangible movables) yang dikenal pertama kali pada negara dengan sistem hukum anglo saxon (common law system).

Hak merek dapat dianggap sebagai aset yang bernilai, hal ini dikarenakan karya-karya intelektual dalam bidang ilmu pengetahuan, seni, sastra, atau teknologi yang dilahirkan dengan pengorbanan tenaga, waktu, dan biaya, menjadikannya berharga dan bernilai. Manfaat ekonomis yang dapat dinikmati dan nilai ekonomis yang melekat memunculkan konsep property terhadap karya-karya intelelektual

\footnotetext{
${ }^{8}$ Tim Lindsey dkk. Hak Kekayaan Intelektual (Jakarta: Alumni, 2006) h. 131

${ }^{9}$ Apeldorn, L.J. Van. Pengantar Ilmu Hukum (Jakarta: Pradnya Paramita,1980) h. 215

${ }^{10}$ Tutik Tri Wulan. Hukum Perdata dalam Sistem Hukum Nasional (Jakarta: Kencana Prenada Media, 2008), h. 142-143
}

tersebut. Bagi dunia usaha, karya-karya tersebut dapat disebut sebagai aset perusahaan. ${ }^{11}$ Menurut Undang-Undang Merek Pasal 40, menyebutkan bahwa hak atas merek terdaftar dapat beralih atau dialihkan karena: (a) pewarisan; (b) wasiat; (c) hibah; (d) perjanjian; atau (e) sebab-sebab lain yang dibenarkan oleh peraturan perundangundangan.

Dalam hukum Islam melalui fatwa MUI Nomor 1/MUNAS VII/MUI/5/2005 Tentang Perlindungan Hak Kekayaan Intelektual (HKI) menyatakan bahwa hak merek yang merupakan HKI (hak kekayaan intelektual) dipandang sebagai salah satu huqûq mâlîyyah (hak kekayaan) yang mendapat perlindungan hukum (mashûn) sebagaimana mâl (kekayaan).

\section{Hak Merek Sebagai Obyek Perjanjian Rahn}

Marhûn adalah salah satu syarat syahnya perjanjian rahn. Marhûn merupakan barang yang dijadikan jaminan oleh rahn. Para ulama fiqih sepakat mensyaratkan marhûn sebagaimana persyaratan barang dalam jual beli sehingga barang tersebut dapat dijual untuk memenuhi hak murtahîn (Ibnu Qudamah, Mughnî al-Muhtâj 4/337). Ulama Hanafiyah mensyaratkan marhûn antara lain: (a) Barang dapat diperjual belikan; (b) Bermanfaat; (c) Barangnya harus jelas; (d) Milik rahîn; (e) Tidak bersatu dengan harta lain; (f) Dipegang (dikuasai) oleh rahîn; (g) Harta yang tetap atau dapat dipindahkan. ${ }^{12}$ Berikut ini akan dijelaskan mengenai hak merek sebagai marhûn dengan menggunakan persyaratan marhûn oleh ulama Hanafiyah: (1) Benda harus dapat dîperjualbelîkan. Hak merek sebagai hak yang mempunyai nilai ekonomis telah diatur di dalam Pasal 40 Undang-Undang Nomor 15 Tahun 2001 tentang Merek yang menyebutkan bahwa merek dapat diperjual belikan yaitu melalui perjanjian. Berikut ini adalah bunyi pasal 40 UUM: (1) Hak atas merek terdaftar dapat beralih atau dialihkan karena: (a) pewarisan;

\footnotetext{
${ }^{11}$ Bambang Kesowo. Pengantar Hukum Mengenai HKI di Indonesia (Yogyakarta: Fakultas Hukum UGM, 1995), h. 5

Al-Kasani, Al-Badai' Ash-Shana'i fi Tartib Asy-

Syara'i, juz 6: 135-140
} 
(b) wasiat; (c) hibah; (d) perjanjian atau (e) sebab-sebab lain yang dibenarkan oleh peraturan perundang-undangan. (2) Pengalihan hak atas merek sebagaimana dimaksud pada ayat (1) wajib dimohonkan pencatatannya kepada Direktorat Jenderal untuk dicatat dalam Daftar Umum Merek. (3) Permohonan pengalihan hak atas merek sebagaimana dimaksud pada ayat (2) disertai dengan dokumen yang mendukungnya.(4) Pengalihan hak atas merek terdaftar yang telah dicatat sebagaimana dimaksud pada ayat diumumkan dalam Berita Resmi Merek. (5) Pengalihan hak atas merek terdaftar yang tidak dicatatkan dalam Daftar Umum merek tidak berakibat hukum pada pihak ketiga. (6) Pencatatan pengalihan hak atas merek sebagaimana dimaksud pada ayat (1) dikenai biaya sebagaimana diatur dalam undang-undang ini. (a) Benda harus mempunyâ̂ manfaat. Hak merek sebagaimana diatur di dalam undangundang merek mempunyai manfaat yaitu sebagai alat pembeda antara barang dan atau jasa lainnya, digunakan dalam kegiatan perdagangan barang atau jasa. Hak merek bermanfaat untuk menjaga reputasi barang/jasa yang dihasilkan perusahaan dan juga melindungi konsumen dari kwalitas barang yang mungkin lebih rendah dan dibuat oleh pesaing pelaku usaha dengan cara curang atau penipuan. (b) Benda harus jelas. Jelas yang dimaksud adalah dapat dilihat atau dapat dinikmati. Hak merek adalah hak kekayaan industry yang bisa dinikmati tapi tidak dapat dilihat. Merek yang ada jelas bentuk dan wujudnya bisa dalam bentuk logo ataupun gambar, namun hak atas merek tidak dapat dilihat. Hak merek merupakan jenis benda yang bergerak dan tidak berwujud. (c) Benda adalah mîlîk râhîn. Hak merek sebagaimana diatur di dalam UU dapat dimiliki oleh pelaku usaha bisa perorangan atau badan hukum. Kepemilikan atas hak merek dapat diajukan melalui Dirjen HKI yaitu melalui pendaftaran merek. Pemerintah akan melindungi pemilik merek berdasarkan pendaftaran. Bagi pelaku usaha yang tidak mendaftarkan merek, maka mereka tidak akan mendapatkan perlindungan hukum. Hal ini sesuai dengan prinsip konstitutif yang dipakai di dalam perlindungan hak kekayaan industri. (d) Benda tîdak bersatu dengan harta yang laîn. Hak merek dalam hal ini menurut penulis adalah hak atas suatu merek tertentu dan dimiliki perusahaan tertentu. Hak merek dalam bentuk wujudnya dapat dilihat dalam bentuk sertifikat kepemilikan atas merek. Hak merek terpisah dengan benda-benda riil perusahaan seperti mesin dan bangunan. (e) Benda dîpegang oleh râhîn. Merek yang sudah didaftarkan tentunya akan digunakan pelaku usaha dalam menjalankan kegiatan perdagangan. Hak merek dalam wujudnya adalah dalam bentuk sertifikat yang mana sertifikat tersebut dipegang oleh pelaku usaha. Melalui pendaftaran merek di Dirjen HKI maka secara otomatis merek yang sudah terdaftar menjadi milik pemohon pendaftaran (pelaku usaha yang berkepentingan). (f) Harta tetap atau dapat dîpîndahkan. Hak merek sebagaimana diatur di dalam UU merek menyatakan bahwa hak merek dapat dipindahkan yaitu hak atas merek terdaftar dapat beralih atau dialihkan karena pewarisan, wasiat, hibah, perjanjian atau sebab-sebab lain yang dibenarkan oleh peraturan perundang-undangan.

Uraian diatas telah dapat menjelaskan bahwa hak merek sudah memenuhi syarat sebagai benda atau marhûn sebagaimana yang diisyaratkan di dalam perjanjian rahn. Selain penjelasan menurut ulama Hanafiah di atas MUI juga telah menjelaskan tentang keberadaan hak merek di dalam kajian fiqih. Berikut ini adalah uraian Keputusan Fatwa MUI Nomor: 1/MUNAS VII/MUI/5/2005 Tentang Perlindungan Hak Kekayaan Intelektual (HKI) Fatwa MUI yang mengeluarkan ketentuan: (1) Dalam hukum Islam, HKI dipandang sebagai salah satu huqûq mâlîyyah (hak kekayaan) yang mendapat perlindungan hukum (mashûn) sebagaimana mal (kekayaan); (2) HKI yang mendapat perlindungan hukum Islam sebagaimana dimaksud angka 1 tersebut adalah HKI yang tidak bertentangan dengan hukum Islam; (3) HKI dapat dijadikan obyek akad (al-ma'qûd 'alaîh), baik akad mu'awadhah (pertukaran, komersial), maupun akad tabarru'at (non komersial), serta dapat diwaqafkan dan diwariskan; (4) Setiap bentuk pelanggaran terhadap HKI, termasuk namun tidak terbatas pada menggunakan, mengungkapkan, membuat, memakai, menjual, mengimpor, mengekspor, mengedarkan, menyerahkan, 
Khoirul Hidayah, Kajian Hukum Islam Terhadap Hak Merek...| 7

menyediakan, mengumumkan, memperbanyak, menjiplak, memalsu, membajak HKI milik orang lain secara tanpa hak merupakan kedzaliman dan hukumnya adalah harâm.

Keberadaan hak merek sebagai obyek benda dalam perjanjian rahn jika merujuk pada ketentuan MUI tersebut di atas maka: Pertama, hak merek merupakan bagian dari Hak Kekayaan Intelektual yang dipandang sebagai mal (harta) dan terdapat hak atas harta kekayaan perusahaan (huqûq mâlîyyah). Keputusan Majma' al-Fiqh al-Islami Nomor 43 (5/5) Mu'tamar V tahun 1409 H/1988 M tentang al-Huquq al-Ma'nawiyyah: (a) Nama dagang, alamat dan mereknya, serta hasil ciptaan (karang-mengarang) dan hasil kreasi adalah hak-hak khusus yang dimiliki oleh pemiliknya, yang dalam abad moderen hak-hak seperti itu mempunyai nilai ekonomis yang diakui orang sebagai kekayaan. Oleh karena itu, hak-hak seperti itu tidak boleh dilanggar; (b) Pemilik hak-hak non-material seperti nama dagang, alamat dan mereknya, dan hak cipta mempunyai kewenangan terhadap haknya itu, dan bisa ditransaksikan dengan sejumlah uang dengan syarat terhindar dari berbagai ketidakpastian dan tipuan, seperti halnya dengan kewenangan seseorang terhadap hakhak yang bersifat material; (c) Hak cipta, karang-mengarang dan hak cipta lainnya dilindungi oleh syara'. Pemiliknya mempunyai kewenangan terhadapnya dan tidak boleh dilanggar. Kedua, hak merek merupakan hak yang dapat memberikan manfaat bagi perusahaan ataupun konsumen di dalam praktek perdagangan. Hal ini tentunya dapat menjelaskan bahwa hak merek adalah bukan hak kekayaan industry atau benda yang dilarang oleh hukum Islam. Hak merek dalam hal ini tidak melanggar ketentuan baik yang ada di dalam al Qur'an ataupun hadist. Ketîga, hak merek dapat dijadikan sebagai obyek perjanjian baik perjanjian mu'âwadhah (pertukaran, komersial), maupun perjanjian tabarru'at (non komersial), serta dapat diwaqafkan dan diwariskan. Ketentuan ini dapat menjelaskan bahwa hak merek juga dapat dijadikan sebagai obyek dalam perjanjian rahn.

Pendapat ulama tentang hak merek juga dapat dilihat dari dasar keputusan MUI, antara lain:" "Mayorîtas ulama darî kalangan mazhab Malîkî, Syafì'î dan Hanbalî berpendapat bahwa hak cîpta atas cîptaan yang orsînal dan manfaat tergolong harta berharga sebagaîmana benda jîka boleh dîmanfaatkan secara syara' (hukum Îslam)."14 Berkenaan dengan hak kepengarangan (haqq al-ta'liff), salah satu hak cipta, Wahbah alZuhaili menegaskan: "Berdasarkan hal (bahwa hak kepengarangan adalah hak yang dîlîndungî oleh syara'/ hukum Îslam atas dasar qaîdah îstîshlah) tersebut, mencetak ulang atau men-copy buku (tanpa îzîn yang sah) dîpandang sebagaî pelanggaran atau kejahatan terhadap hak pengarang; dalam artî bahwa perbuatan tersebut adalah kemaksîatan yang menîmbulkan dosa dalam pandangan syara' dan merupakan pencurîan yang

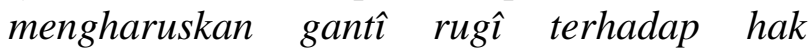
pengarang atas naskah yang dîcetak secara melanggar dan zalîm, serta menîmbulkan kerugîan morîl yang menîmpanya."

Kutiban di atas meskipun menjelaskan tentang hak cipta, namun keberadaan hak merek adalah sama dengan hak cipta. Hak merek yang dianggap sebagai benda, maka menurut Wahbah Zuhaili, jika ada yang menggunakan tanpa seijin pemiliknya dan mengakibatkan kerugian baik secara moril ataupun ekonomis maka hal tersebut tidak dibenarkan menurut hukum Islam dan dianggap $d z a ̂ l i ̂ m$. Penjelasan tersebut di atas dapat menjadi pertimbangan bahwa memang hak merek dapat dikategorikan sebagai benda/ harta yang kemudian tentunya dapat dijadikan sebagai obyek benda dalam perjanjian rahn yaitu sebagai syarat rukunnya perjanjian yaitu marhûn.

Hak merek sebagai obyek dalam perjanjian rahn tentunya tidak terlepas dari pembahasan tentang penggunaan jaminan di dalam praktek pembiayaan. Perjanjian rahn jika kita membahas jaminan dalam hukum jaminan, maka rahn adalah dipersamakan dengan gadai, jika benda yang dijadikan obyek

\footnotetext{
13 Keputusan Fatwa MUI Nomor 1/MUNAS VII/MUI/5/2005 Tentang Perlindungan Hak Kekayaan Intelektual (HKI)

14 Fathi al-Duraini. Haqq al-Ibtikar fi al-Fiqh al-Islami al-Muqaran (Bairut: Mu'assasah al-Risalah, 1984), h. 20.
} 
jaminan perjanjian rahn adalah benda bergerak. Dalam praktek perbankan di Indonesia, pengaturan tentang jaminan / collateral / agunan yang dapat digunakan telah diatur dalam Peraturan Bank Indonesia Nomor 7/2/PBI/2005 tentang Penilaian Aktiva Bank Umum, dimana pada Pasal 46 menyebutkan: (a) Surat Berharga dan saham yang aktif diperdagangkan di bursa efek di Indonesia atau memiliki peringkat investasi dan diikat secara gadai; (b) Tanah, rumah tinggal dan gedung yang diikat dengan hak tanggungan; (c) Pesawat udara atau kapal laut dengan ukuran di atas 20 (dua puluh) meter kubik yang diikat dengan hipotek, dan atau (d) Kendaraan bermotor dan persediaan yang diikat secara fidusia.

Jika merujuk pada ketentuan di atas, maka hak merek sebagai benda dapat dibuktikan dalam bentuk sertifikat yang dapat dijadikan sebagai obyek perjanjian hutang piutang, dan dalam bentuk pengikatannya adalah gadai. Namun di dalam praktek, sertifikat hak merek bukan merupakan surat berharga sebagaimana saham dan obligasi. Sehingga untuk penggunaan hak merek yang diikat dengan gadai diperlukan kajian lebih mendalam, karena hal ini terkait masalah teknis dan hukum positif yang sudah tersedia. Konsep ini meskipun masih dalam tahapan wacana, namun dalam perkembangan penggunaan jaminan hak merek ke depan tentunya dapat menjadi alternative bagi pelaku usaha dan juga pemerintah untuk menjadi bagian dari solusi dalam praktek pembiayaan modal usaha di Indonesia. Sebagaimana fenomena hasil pertanian yang sebelumnya tidak dapat dijadikan jaminan, namun guna membantu petani dalam permodalan, maka petani sekarang dapat menggunakan hasil pertaniannya untuk dijadikan sebagai obyek jaminan yaitu dalam bentuk resi gudang.

\section{DAFTAR PUSTAKA}

Ath-Thayar, Abdullah bin Muhammad, Abdullah bin Muhammad al-Muthliq, dan Muhammad bin Ibrahim Alu Musa. Al-Fîqh Al-Muyassarah: Qîsmul Mu'amalah. Riyadh: Madar al-Wathani lin Nasyr, 1425H.

\section{Kesimpulan}

Hak merek yang terdaftar melalui dirjen HKI sebagai hak kekayaan industri dapat meningkatkan reputasi perusahaan melalui upaya perlindungan konsumen dari kwalitas barang yang tidak baik. Menurut hukum positif ataupun hukum Islam yang berlaku di Indonesia, hak merek merupakan benda yang dapat dialihkan. Hak merek sebagai benda yang dapat dialihkan, tentunya memiliki nilai ekonomi yang tinggi bagi perusahaan. Sebagai benda bergerak yang tidak berwujud, sebagaimana juga dijelaskan dalam fatwa MUI tahun 2005, hak merek adalah harta yang dapat diperjualbelikan.Ulama Hanafiah juga telah menjelaskan perjanjian rahn yang mensyaratkan adanya marhûn. Berdasarkan persyaratan marhûn yang dibuat oleh ulama Hanafiah, maka dapat dijelaskan bahwa hak merek telah memenuhi persyaratan marhûn. Penjelasan ini telah menyimpulkan bahwa hak merek dapat dijadikan sebagai obyek benda di dalam perjanjian rahn.

Kajian hak merek sebagai obyek dalam perjanjian rahn merupakan wacana yang tentunya belum serta merta dapat dipakai di dalam praktek. Dikatakan demikian karena untuk mengimplementasikan ide tersebut, diperlukan perangkat kebijakan yang mengatur secara khusus mengenai penggunaan hak merek di dalam perjanjian rahn. Semoga kajian ini dapat menjadi tambahan wacana bagi perkembangan ekonomi syariah di Indonesia khususnya bagi lembaga pembiayaan yang berbasis syariah. Perkembangan perdagangan di era globalisasi telah menuntut para pelaku usaha dan pemerintah untuk selalu melakukan inovasi-inovasi dalam pembiayaan modal yang nantinya diharapkan mampu membantu pelaku usaha kecil menengah (UMKM) sehingga dapat bersaing di pasar global.

Al-Zuhaili, Wahbah. Al-Mu'amalat AlMalîyyah Al-Mu'ashîrah Buhuts $W a$ Fatawa Wa Hulul. Beirut: Dar AlMu'ashirah, 2002.

Apeldorn, L.J. Van. Pengantar Îlmu Hukum. Jakarta: Pradnya Paramita, 1980. 
Khoirul Hidayah, Kajian Hukum Islam Terhadap Hak Merek...| 9

Ghazaly, Abdul Rahman, Ghufron Ihsan, Sapiudin Shidiq. Fiqh Muamalah. Jakarta: Kencana Prenada Media Group, 2010.

Kesowo, Bambang. Pengantar Hukum Mengenaî HKÎ dî Îndonesîa. Yogyakarta: Fakultas Hukum UGM, 1995.

Keputusan Fatwa MUI Nomor: 1/MUNAS VII/MUI/5/2005 Tentang Perlindungan Hak Kekayaan Intelektual (HKI).

Lindsey, Tim, dkk. Hak Kekayaan Intelektual. Jakarta: Penerbit Alumni. 2006.
Peraturan Mahkamah Agung No. 2 Tahun 2008 tentang Kompilasi Hukum Ekonomi Islam.

Rusyd, Ibnu. Bîdayatul Mujtahîd Wa Nîhayatul Muqtashîd II.

Tutik, Tri Wulan. Hukum Perdata dalam Sîstem Hukum Nasîonal. Jakarta: Kencana Prenada Media Group, 2008 Utomo, Tomi Suryo. Hak Kekayaan Intelektual dî Era Globalîsasî. Yogyakarta: Graha Ilmu, 2010

Undang-Undang Republik Indonesia Nomor 15 Tahun 2001 tentang Merek. 